Article

\title{
Anti-Inflammatory Activity of Some Characteristic Constituents from the Vine Stems of Spatholobus suberectus
}

\author{
Xiao-Yan Liu ${ }^{1}$, You-Bo Zhang ${ }^{1}$, Xiu-Wei Yang ${ }^{1, *}$, Yan-Fang Yang ${ }^{1}$, Wei Xu ${ }^{1}$, Wei Zhao ${ }^{2}$, \\ Kai-Feng Peng ${ }^{2}$, Yun Gong ${ }^{2}$, Ni-Fu Liu ${ }^{2}$ and Peng Zhang ${ }^{2}$ \\ 1 State Key Laboratory of Natural and Biomimetic Drugs, Department of Natural Medicines, \\ School of Pharmaceutical Sciences, Peking University Health Science Center, Peking University, No. 38, \\ Xueyuan Road, Haidian District, Beijing 100191, China; yanzi_89@163.com (X.-Y.L.); \\ zybo5288@163.com (Y.-B.Z.); yangyanfang@bjmu.edu.cn (Y.-F.Y.); high-xu@163.com (W.X.) \\ 2 Zhuzhou Qianjin Pharmaceutical Co., Ltd., Zhuzhou 412000, China; zw18273285046@163.com (W.Z.); \\ kaikai81234@163.com (K.-F.P.); gongyun2002@126.com (Y.G.); 15873315432@163.com (N.-F.L.); \\ pengzhangbjmu@163.com (P.Z.) \\ * Correspondence: xwyang@bjmu.edu.cn; Tel.: +86-10-8280-1569; Fax: +86-10-8280-2724
}

Received: 22 September 2019; Accepted: 14 October 2019; Published: 17 October 2019

\begin{abstract}
The dried vine stems of Spatholobus suberectus are commonly used in traditional Chinese medicine for treating gynecological and cardiovascular diseases. In this study, five new compounds named spasuberol A (2), homovanillyl-4-oxo-nonanoate (5), spasuberol C (6), spasuberoside A (14), and spasuberoside $B(\mathbf{1 5})$, together with ten known compounds $(\mathbf{1}, \mathbf{3}, \mathbf{4}, \mathbf{7 - 1 3})$, were isolated from the dried vine stems of $S$. suberectus. Their chemical structures were analyzed using spectroscopic assays. This is the first study interpreting the detailed structural information of 4 . The anti-inflammatory activity of these compounds was evaluated by reducing nitric oxide overproduction in RAW264.7 macrophages stimulated by lipopolysaccharide. Compounds $\mathbf{1}$ and $\mathbf{8 - 1 0}$ showed strong inhibitory activity with half maximal inhibitory concentration $\left(\mathrm{IC}_{50}\right)$ values of $5.69,16.34,16.87$, and $6.78 \mu \mathrm{M}$, respectively, exhibiting higher activity than the positive drug L- $N^{6}$-(1-iminoethyl)-lysine (L-NIL) with an $\mathrm{IC}_{50}$ value of $19.08 \mu \mathrm{M}$. The $\mathrm{IC}_{50}$ values of inhibitory activity of compounds $\mathbf{2}$ and $\mathbf{4}-\mathbf{6}$ were $46.26,40.05,45.87$, and $28.29 \mu \mathrm{M}$ respectively, which were lower than L-NIL, but better than that of positive drug indomethacin with an $\mathrm{IC}_{50}$ value of $55.44 \mu \mathrm{M}$. Quantitative real-time polymerase chain reaction analysis revealed that assayed compounds with good anti-inflammatory activity, such as 1, 6, 9, and 10 at different concentrations, can reduce the messenger RNA (mRNA) expression of some pro-inflammatory cytokines such as tumor necrosis factor $\alpha$ (TNF- $\alpha$ ), nitric oxide synthase (iNOS), and cyclooxygenase 2 (COX-2). The anti-inflammatory activity and the possible mechanism of the compounds mentioned in this paper were studied preliminarily.
\end{abstract}

Keywords: Spatholobus suberectus; isoflavones; inhibition of nitric oxide production; anti-inflammatory activity; RAW264.7 macrophage cells

\section{Introduction}

Spatholobi caulis (SPC), belonging to family Leguminosae, is the dried vine stem of Spatholobus suberectus Dunn, chiefly distributed in Fujian Province and the Guangxi Zhuang autonomous region of China. SPC is an important ingredient of traditional Chinese medicine (TCM) recorded in the Pharmacopoeia of the People's Republic of China [1], with demonstrated blood-activating and stasis-dissolving efficacy. In clinical practice, it is always used for treating rheumatic arthralgia, irregular menstruation, and paralysis in many Chinese formulas such as Jinkui Shenqi pills and Fukeqianjin 
formula (a classical prescription). Diverse pharmacological actions such as anti-inflammatory, anti-virus, hemagglutination, and lipid regulation were reported recently [2-5]. For chemical analysis, many active ingredients including flavonoids, isoflavones, and anthocyanins, with antioxidant activities [6,7], as well as the ability to treat renal injury [8] and adjust cholesterol metabolism in SPC [9], were isolated and identified, which inspired its further research.

Under the stimuli of mucosal injury, cellular damage, bacterial or viral infections, and other forms of cellular oxidative stress, different types of inflammatory responses can be caused, whereby pattern recognition receptors characterizing pathophysiological processes can be activated to identify the toxins infecting the host, such as lipopolysaccharide (LPS), lipoproteins, and lipoteichoic acids [10-12]. LPS is a surface antigen of the outer membrane of Gram-negative bacteria, through which macrophage cells are stimulated, thereby starting a cascade of reactions activating the release of nitric oxide (NO), prostaglandins, tumor necrosis factor $\alpha$ (TNF- $\alpha)$, pro-inflammatory cytokines interleukin 6 (IL-6) and cyclooxygenase 2 (COX-2), and other inflammatory mediators in the process of bacterial infection [13-15]. As an essential part of biochemical messengers involved with many physiological functions and immune responses, these inflammatory mediators play a complex role in inflammatory response; therefore, reducing inflammation by inhibiting the production of inflammatory mediators is a potential method of developing anti-inflammatory drugs. On the basis of the current struggle to discover more natural products as valuable resources for lead compounds for drug and pesticide design, the present study aims to identify more anti-inflammatory compounds in SPC, and further investigate the possible mechanism of NO inhibitory action of these isolated compounds using real-time quantitative polymerase chain reaction (qPCR).

\section{Results and Discussion}

\subsection{Extraction and Isolation}

The dried vine stems of Spatholobus suberectus $(70 \mathrm{~kg})$ were chopped and extracted with water (350 $\mathrm{L}$ twice, $2 \mathrm{~h}$ each) under reflux, and the combined extracts were concentrated at $75^{\circ} \mathrm{C}$ in vacuum for 7 $\mathrm{h}$ to obtain a dry extractum $(6 \mathrm{~kg})$. The extractum was then suspended in water and segmented with ethyl acetate (EtOAc) and normal butanol $(n-\mathrm{BuOH})$ to obtain the corresponding extract.

The EtOAc extract $(270 \mathrm{~g})$ was separated into seven fractions (Fr.1-Fr.7) by open silica gel column chromatography (SGCC) and eluted sequentially with chloroform $\left(\mathrm{CHCl}_{3}\right)$-methanol $(\mathrm{MeOH})(80: 1$, 50:1, 30:1, 20:1, 10:1, 5:1, and 1:1, v/v). Fr.1 (19.9 g) was again eluted with CHCl3-MeOH (60:1, 40:1, 20:1, 10:1, 5:1, and 1:1, v/v) through open SGCC to yield six fractions (Fr.1A-F). The crystalline part of Fr.1A was purified by recrystallization in $\mathrm{MeOH}$ to obtain compound $\mathbf{1}(20.2 \mathrm{mg})$, while the amorphous part was divided into seven fractions (Fr.1A1-7) eluted with $\mathrm{CHCl} 3-\mathrm{MeOH}(60: 1, v / v)$. Fr.1A7 was separated by reversed-phase semi-preparative HPLC (RPSP-HPLC) and eluted with $\mathrm{MeCN}-\mathrm{H}_{2} \mathrm{O}$ (36:64, v/v, $8 \mathrm{~mL} / \mathrm{min}$ ); at a retention time $\left(t_{R}\right)$ of $58.2 \mathrm{~min}$, compound 2 was obtained with a quality of $19.8 \mathrm{mg}$. Fr.1C was subjected to SGCC to get three fractions (Fr.1C1-3) with CHCl3-MeOH (40:1, $v / v)$ as the elution phase, and compound 3 was isolated from Fr.1C3 using $\mathrm{MeCN}-\mathrm{H}_{2} \mathrm{O}(35: 65, v / v$, $8 \mathrm{~mL} / \mathrm{min}$ ) as the elution that flowed through RPSP-HPLC. Fr.1D was sectioned to yield three fractions

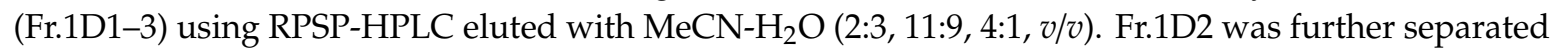
and purified with $\mathrm{MeCN}-\mathrm{H}_{2} \mathrm{O}(36: 64, v / v, 8 \mathrm{~mL} / \mathrm{min})$ by RPSP-HPLC, and compounds $4\left(16.5 \mathrm{mg}\right.$, $\mathrm{t}_{\mathrm{R}}$ $37.6 \mathrm{~min})$ and $5\left(5.6 \mathrm{mg}, \mathrm{t}_{\mathrm{R}} 39.1 \mathrm{~min}\right)$ were obtained. Fr.1E yielded compound $6(8.3 \mathrm{mg})$ and two subfractions (Fr.1E1-2) after being subjected to Sephadex LH-20 CC using MeOH as the elution. Fr.1E2 was further detected by thin-layer chromatography (TLC) before being sectioned using RPSP-HPLC with $\mathrm{MeCN}_{-} \mathrm{H}_{2} \mathrm{O}(36: 64, v / v, 8 \mathrm{~mL} / \mathrm{min})$ as the mobile phase, from which compound $7\left(11.4 \mathrm{mg}, \mathrm{t}_{\mathrm{R}} 26.3\right.$ $\mathrm{min})$ was afforded.

Fr.2 (3.98 g) was gradually eluted with CHCl3-MeOH (100:1, 50:1, 20:1, 10:1, and 5:1, v/v) on SGCC to achieve five fractions (Fr.2A-E). Compound 8 (37.6 $\mathrm{mg}, \mathrm{t}_{\mathrm{R}} 45.9 \mathrm{~min}$ ) was obtained from Fr.2C using $\mathrm{MeCN}^{-} \mathrm{H}_{2} \mathrm{O}(22: 78, v / v, 8 \mathrm{~mL} / \mathrm{min})$ as the mobile phase pumped through RPSP-HPLC. 
Fr.2D was further sectioned and purified with $\mathrm{MeCN}_{-} \mathrm{H}_{2} \mathrm{O}(27: 73, v / v, 8 \mathrm{~mL} / \mathrm{min})$ using RPSP-HPLC to get compounds $9\left(52.7 \mathrm{mg}, \mathrm{t}_{\mathrm{R}} 48.7 \mathrm{~min}\right)$ and $10\left(48.2 \mathrm{mg}, \mathrm{t}_{\mathrm{R}} 70.2 \mathrm{~min}\right)$. Fr.4 (26.6 g) yielded five fractions (Fr.4A-E) after being subjected to SGCC with a gradient of CHCl3-MeOH (80:1, 60:1, 40:1, 20:1, and 10:1, $v / v)$ as the elution. Fr.4A was segmented by RPSP-HPLC with MeCN- $\mathrm{H}_{2} \mathrm{O}(35: 65, v / v$, $15 \mathrm{~mL} / \mathrm{min}$ ) as the mobile phase, and then purified by Sephadex LH-20 CC using MeOH as the elution to afford compounds $11(422 \mathrm{mg})$ and $12(68 \mathrm{mg})$. Fr.4D was purified repeatedly with the elution of MeOH on Sephadex LH-20 CC, and compound 13 (31.3 mg) was afforded. Fr.5 (25 g) was submitted to RPSP-HPLC with MeCN-H $\mathrm{H}_{2} \mathrm{O}(10: 90, v / v, 15 \mathrm{~mL} / \mathrm{min})$ as the mobile phase to obtain three fractions (Fr.5A-C). Fr.5A was purified repetitively with MeOH on Sephadex LH-20 CC to yield compound 14 (7.7 mg). Fr.6 (26.6 g) yielded three fractions (Fr.6A-C) after being fractionated by RPSP-HPLC eluted with $\mathrm{MeCN}-\mathrm{H}_{2} \mathrm{O}(10: 90, v / v, 15 \mathrm{~mL} / \mathrm{min})$; the middle fraction was further separated by RPSP-HPLC, and compound 15 (38.2 $\left.\mathrm{mg}, \mathrm{t}_{\mathrm{R}} 49.9 \mathrm{~min}\right)$ was obtained using $\mathrm{MeCN}-\mathrm{H}_{2} \mathrm{O}$ (22:78, v/v, $\left.8 \mathrm{~mL} / \mathrm{min}\right)$.

Spasuberol A $\left((3 S, 4 R)-7,2^{\prime}\right.$-dihydroxy-8-methoxy-4', $5^{\prime}$-methylenedioxy-isoflavan-4-ol, 2): white powder $\left(\mathrm{MeCN}-\mathrm{H}_{2} \mathrm{O}\right) ;[\alpha]^{25} \mathrm{D}^{-450.0}$ (c 0.2, MeOH); ultraviolet (UV) $(\mathrm{MeOH}) \lambda_{\max } \mathrm{nm}(\log \varepsilon): 203$ (4.38), 309 (3.45); infrared (IR) (KBr) $\nu_{\max }: 3397,2929,1612,1500,1473,1458,1144,1056,1032 \mathrm{~cm}^{-1}$; for ${ }^{1} \mathrm{H}$ NMR and ${ }^{13} \mathrm{C}$ NMR data, see Table 1 ; high-resolution (HR) electrospray ionization (ESI) MS $m / z$ $331.0840[\mathrm{M}-\mathrm{H}]^{-}$(calculated for $\mathrm{C}_{17} \mathrm{H}_{15} \mathrm{O}_{7}, 331.0823$ ).

Table 1. ${ }^{1} \mathrm{H}(400 \mathrm{MHz})$ and ${ }^{13} \mathrm{C}(100 \mathrm{MHz})$ NMR data for compounds 2 and 4 in dimethyl sulfoxide (DMSO)- $d_{6}$.

\begin{tabular}{|c|c|c|c|c|}
\hline \multirow{2}{*}{ No. } & \multicolumn{2}{|l|}{2} & \multicolumn{2}{|l|}{4} \\
\hline & $\delta_{\mathrm{H}}(J$ in $\mathrm{Hz})$ & $\delta_{C}$ (mult.) $^{a}$ & $\delta_{\mathrm{H}}(J$ in $\mathrm{Hz})$ & $\delta_{\mathrm{C}}$ (mult.) $^{\mathrm{a}}$ \\
\hline 2 & $\begin{array}{c}3.61, \mathrm{t}(9.7) \\
4.29, \mathrm{dd}(9.7,3.5)\end{array}$ & $66.1\left(\mathrm{CH}_{2}\right)$ & $\begin{array}{c}3.60, \mathrm{t}(10.0) \\
4.22, \mathrm{dd}(10.0,3.7)\end{array}$ & $65.9\left(\mathrm{CH}_{2}\right)$ \\
\hline 3 & 3.56, ddd $(9.7,7.0,3.5)$ & $39.4(\mathrm{CH})$ & $3.55, \mathrm{~m}$ & $39.9(\mathrm{CH})$ \\
\hline 4 & $5.52, \mathrm{~d}(7.0)$ & $77.9(\mathrm{CH})$ & $5.50, \mathrm{~d}(6.8)$ & $78.2(\mathrm{CH})$ \\
\hline 5 & $6.99, \mathrm{~d}(8.5)$ & $125.7(\mathrm{CH})$ & $7.24, \mathrm{~d}(8.4)$ & $132.2(\mathrm{CH})$ \\
\hline 6 & $6.55, \mathrm{~d}(8.5)$ & $110.1(\mathrm{CH})$ & $6.47, \mathrm{dd}(8.4,2.4)$ & $109.9(\mathrm{CH})$ \\
\hline 7 & - & $151.3(\mathrm{C})$ & - & $158.9(\mathrm{C})$ \\
\hline 8 & - & $135.8(\mathrm{C})$ & $6.27, \mathrm{~d}(2.4)$ & $103.0(\mathrm{CH})$ \\
\hline 9 & - & $149.7(\mathrm{C})$ & - & $156.5(\mathrm{C})$ \\
\hline 10 & - & $112.5(\mathrm{C})$ & - & $111.4(\mathrm{C})$ \\
\hline $1^{\prime}$ & - & $118.5(\mathrm{C})$ & - & $118.6(\mathrm{C})$ \\
\hline $2^{\prime}$ & - & $153.9(\mathrm{C})$ & - & $153.9(\mathrm{C})$ \\
\hline $3^{\prime}$ & $6.52, \mathrm{~s}$ & $93.3(\mathrm{CH})$ & $6.52, \mathrm{~s}$ & $93.4(\mathrm{CH})$ \\
\hline $4^{\prime}$ & - & $147.6(\mathrm{C})$ & - & $147.6(\mathrm{C})$ \\
\hline $5^{\prime}$ & - & $141.2(\mathrm{C})$ & - & $141.2(\mathrm{C})$ \\
\hline $6^{\prime}$ & $6.97, \mathrm{~s}$ & $105.5(\mathrm{CH})$ & $6.96, \mathrm{~s}$ & $105.5(\mathrm{CH})$ \\
\hline $3-\mathrm{OCH}_{3}$ & $3.66, \mathrm{~s}$ & $60.2\left(\mathrm{CH}_{3}\right)$ & - & - \\
\hline$-\mathrm{OCH}_{2} \mathrm{O}-$ & $5.91, \mathrm{~d}(0.9) ; 5.95, \mathrm{~d}(0.9)$ & $101.2\left(\mathrm{CH}_{2}\right)$ & $5.91, \mathrm{~d}(0.7) ; 5.94, \mathrm{~d}(0.7)$ & $101.2\left(\mathrm{CH}_{2}\right)$ \\
\hline
\end{tabular}

a Attached protons determined by DEPT experiment.

Spasuberol B ((3S,4R)-7,2'-dihydroxy-4', 5' -methylenedioxy-isoflavan-4-ol, 4): white powder $\left(\mathrm{MeCN}-\mathrm{H}_{2} \mathrm{O}\right.$ ); $[\alpha]^{25} \mathrm{D}^{-699.0}$ (c 0.2, MeOH); UV (MeOH) $\lambda_{\max } \mathrm{nm}(\log \varepsilon): 204$ (4.72), 309 (3.75); IR (KBr) $v_{\max }: 3250,2933,1619,1596,1474,1458,1144,1032 \mathrm{~cm}^{-1}$; for ${ }^{1} \mathrm{H}$ NMR and ${ }^{13} \mathrm{C}$ NMR data, see Table 1 ; HR-ESI-MS $m / z 285.0762\left[\mathrm{M}-\mathrm{H}_{2} \mathrm{O}+\mathrm{H}\right]^{+}$(calculated for $\mathrm{C}_{16} \mathrm{H}_{13} \mathrm{O}_{5}$, 285.0763).

Homovanillyl-4-oxo-nonanoate (5): yellow-brown transparent oil $\left(\mathrm{MeCN}_{2} \mathrm{H}_{2} \mathrm{O}\right) ; \mathrm{UV}(\mathrm{MeOH})$ $\lambda_{\max } \mathrm{nm}(\log \varepsilon): 203$ (4.64), 381 (3.67); IR (KBr) $\nu_{\max }: 3418,2932,2256,2128,1713,1645,1517,826$ $\mathrm{cm}^{-1}$; for ${ }^{1} \mathrm{H}$ NMR and ${ }^{13} \mathrm{C}$ NMR data, see Table 2; HR-ESI-MS m/z 321.1699 [M - H] ${ }^{-}$(calculated for $\left.\mathrm{C}_{18} \mathrm{H}_{25} \mathrm{O}_{5}, 321.1702\right)$. 
Table 2. ${ }^{1} \mathrm{H}(400 \mathrm{MHz})$ and ${ }^{13} \mathrm{C}(100 \mathrm{MHz}) \mathrm{NMR}$ data for compounds 5 and 6 in DMSO- $d_{6}$.

\begin{tabular}{|c|c|c|c|c|c|}
\hline \multirow{2}{*}{ No. } & \multicolumn{2}{|c|}{5} & \multirow{2}{*}{ No. } & \multicolumn{2}{|c|}{6} \\
\hline & $\delta_{\mathrm{H}}(J$ in $\mathrm{Hz})$ & $\delta_{C}$ (mult.) ${ }^{a}$ & & $\delta_{\mathbf{H}}(J$ in $\mathrm{Hz})$ & $\delta_{C}$ (mult.) ${ }^{a}$ \\
\hline 1 & - & $128.6(\mathrm{C})$ & 2 & - & $160.5(\mathrm{C})$ \\
\hline 2 & $6.80, \mathrm{~d}(1.9)$ & $113.2(\mathrm{CH})$ & 3 & - & $121.4(\mathrm{C})$ \\
\hline 3 & - & $147.6(\mathrm{C})$ & 4 & $7.78, \mathrm{~s}$ & $142.0(\mathrm{CH})$ \\
\hline 4 & - & $145.3(\mathrm{C})$ & 5 & $7.24, \mathrm{~s}$ & $109.7(\mathrm{CH})$ \\
\hline 5 & $6.69, \mathrm{~d}(8.0)$ & $115.5(\mathrm{CH})$ & 6 & - & $151.0(\mathrm{C})$ \\
\hline 6 & $\begin{array}{c}6.60, \mathrm{dd}(8.0, \\
1.9)\end{array}$ & $121.1(\mathrm{CH})$ & 7 & - & $145.5(\mathrm{C})$ \\
\hline 7 & $2.74, \mathrm{t}(7.0)$ & $36.7\left(\mathrm{CH}_{2}\right)$ & 8 & $6.81, \mathrm{~s}$ & $102.6(\mathrm{CH})$ \\
\hline 8 & $4.13, \mathrm{t}(7.0)$ & $65.0\left(\mathrm{CH}_{2}\right)$ & 9 & - & $149.1(\mathrm{C})$ \\
\hline $1^{\prime}$ & - & $172.4(\mathrm{C})$ & 10 & - & $111.2(\mathrm{C})$ \\
\hline $2^{\prime}$ & $2.44, \mathrm{t}(6.7)$ & $27.8\left(\mathrm{CH}_{2}\right)$ & $1^{\prime}$ & - & $120.6(\mathrm{C})$ \\
\hline $3^{\prime}$ & $2.66, \mathrm{t}(6.7)$ & $34.1\left(\mathrm{CH}_{2}\right)$ & $2^{\prime}$ & - & $145.5(\mathrm{C})$ \\
\hline $4^{\prime}$ & - & $209.1(\mathrm{C})$ & $3^{\prime}$ & - & $140.8(\mathrm{C})$ \\
\hline $5^{\prime}$ & $2.39, \mathrm{t}(7.4)$ & $41.8\left(\mathrm{CH}_{2}\right)$ & $4^{\prime}$ & - & $151.8(\mathrm{C})$ \\
\hline $6^{\prime}$ & $1.45, \mathrm{~m}$ & $23.1(\mathrm{CH} 2)$ & $5^{\prime}$ & $6.64, \mathrm{~d}(8.6)$ & $111.4(\mathrm{CH})$ \\
\hline $7^{\prime}$ & $1.25, \mathrm{~m}$ & $30.9\left(\mathrm{CH}_{2}\right)$ & $6^{\prime}$ & $6.86, \mathrm{~d}(8.6)$ & $125.2(\mathrm{CH})$ \\
\hline $8^{\prime}$ & $1.25, \mathrm{~m}$ & $22.1\left(\mathrm{CH}_{2}\right)$ & $2^{\prime}-\mathrm{OCH}_{3}$ & $3.71, \mathrm{~s}$ & $60.6\left(\mathrm{CH}_{3}\right)$ \\
\hline $9^{\prime}$ & $0.85, \mathrm{t}(7.1)$ & $14.0\left(\mathrm{CH}_{3}\right)$ & $3^{\prime}-\mathrm{OCH}_{3}$ & $3.77, \mathrm{~s}$ & $60.2\left(\mathrm{CH}_{3}\right)$ \\
\hline $3-\mathrm{OCH}_{3}$ & $3.74, \mathrm{~s}$ & $55.7\left(\mathrm{CH}_{3}\right)$ & $4^{\prime}-\mathrm{OCH}_{3}$ & $3.82, \mathrm{~s}$ & $56.2\left(\mathrm{CH}_{3}\right)$ \\
\hline
\end{tabular}

${ }^{a}$ Attached protons determined by DEPT experiment.

Spasuberol C (3-(2', 3', 4'-trimethoxyphenyl)-6,7-dihydroxycoumarin, 6): yellow amorphous powder (MeOH); UV (MeOH) $\lambda_{\max } \mathrm{nm}(\log \varepsilon): 207$ (4.39), 249 (3.66), 356 (3.93); IR (KBr) $v_{\max }$ : 3301, 2937, 1687, 1579, 1509, 1471, $1299 \mathrm{~cm}^{-1}$; for ${ }^{1} \mathrm{H}$ NMR and ${ }^{13} \mathrm{C}$ NMR data, see Table 2; HR-ESI-MS $\mathrm{m} / \mathrm{z}$ $345.0972[\mathrm{M}+\mathrm{H}]^{+}$(calculated for $\mathrm{C}_{18} \mathrm{H}_{17} \mathrm{O}_{7}, 345.0974$ ).

Spasuberoside A ((3S,4R)-4,2'-dihydroxy-4'-methoxy-isoflavanol-7-glucopyranoside, 14): white powder $(\mathrm{MeOH}) ;[\alpha]^{25} \mathrm{D}^{-50.0}$ (c 0.47, MeOH); UV (MeOH) $\lambda_{\max } \mathrm{nm}(\log \varepsilon): 203$ (4.35), 225 (3.51), 285 (3.29); IR (KBr) $v_{\max }$ : 3385, 3205, 2988, 2918, 1624, 1595, 1586, 1508, $1496 \mathrm{~cm}^{-1}$; for ${ }^{1} \mathrm{H}$ NMR and ${ }^{13} \mathrm{C}$ NMR data, see Table 3; HR-ESI-MS $m / z 433.1499\left[\mathrm{M}-\mathrm{H}_{2} \mathrm{O}+\mathrm{H}\right]^{+}$(calculated for $\mathrm{C}_{22} \mathrm{H}_{25} \mathrm{O}_{9}, 433.1499$ ).

Table 3. ${ }^{1} \mathrm{H}(400 \mathrm{MHz})$ and ${ }^{13} \mathrm{C}(100 \mathrm{MHz})$ NMR data for compounds 14 and 15 in DMSO- $d_{6}$.

\begin{tabular}{|c|c|c|c|c|}
\hline \multirow{2}{*}{ No. } & \multicolumn{2}{|l|}{14} & \multicolumn{2}{|l|}{15} \\
\hline & $\delta_{\mathrm{H}}(J$ in $\mathrm{Hz})$ & $\delta_{\mathrm{C}}$ (mult.) ${ }^{\mathrm{a}}$ & $\delta_{\mathrm{H}}(J$ in $\mathrm{Hz})$ & $\delta_{\mathrm{C}}$ (mult.) $^{\mathrm{a}}$ \\
\hline 2 & $\begin{array}{c}\text { 3.64, dd }(9.8,15.9) 4.29 \\
\text { dd }(9.2,9.8)\end{array}$ & $66.1\left(\mathrm{CH}_{2}\right)$ & $\begin{array}{c}3.92, \mathrm{t}(10.2) 4.12, \text { br d } \\
(10.2)\end{array}$ & $69.6\left(\mathrm{CH}_{2}\right)$ \\
\hline 3 & 3.66, ddd $(6.4,9.2,15.9)$ & $39.4(\mathrm{CH})$ & $3.35, \mathrm{~m}$ & $30.9(\mathrm{CH})$ \\
\hline 4 & $5.61, \mathrm{~d}(6.4)$ & $77.9(\mathrm{CH})$ & $\begin{array}{c}\text { 2.76, dd }(15.6,5.0) 2.90 \\
\text { dd }(15.6,10.6)\end{array}$ & $30.0\left(\mathrm{CH}_{2}\right)$ \\
\hline 5 & $7.39, \mathrm{~d}(8.6)$ & $132.1(\mathrm{CH})$ & $6.87, \mathrm{~d}(8.5)$ & $130.3(\mathrm{CH})$ \\
\hline 6 & $6.72, \mathrm{dd}(2.2,8.6)$ & $110.6(\mathrm{CH})$ & $6.29, \mathrm{dd}(8.5,2.4)$ & $108.1(\mathrm{CH})$ \\
\hline 7 & - & $158.6(\mathrm{C})$ & - & $156.6(\mathrm{C})$ \\
\hline 8 & $6.56, \mathrm{~d}(2.2)$ & $104.2(\mathrm{CH})$ & $6.19, \mathrm{~d}(2.4)$ & $102.8(\mathrm{CH})$ \\
\hline 9 & - & $156.4(\mathrm{C})$ & - & $154.9(\mathrm{C})$ \\
\hline 10 & - & $114.3(\mathrm{C})$ & - & $113.1(\mathrm{C})$ \\
\hline $1^{\prime}$ & - & $119.4(\mathrm{C})$ & - & $122.4(\mathrm{C})$ \\
\hline $2^{\prime}$ & - & $160.4(\mathrm{C})$ & - & $156.3(\mathrm{C})$ \\
\hline $3^{\prime}$ & $6.43, \mathrm{~d}(2.1)$ & $96.5(\mathrm{CH})$ & $6.76, \mathrm{~d}(2.4)$ & $102.0(\mathrm{CH})$ \\
\hline $4^{\prime}$ & - & $160.7(\mathrm{C})$ & - & $159.2(\mathrm{C})$ \\
\hline $5^{\prime}$ & $6.45, \mathrm{dd}(2.1,8.1)$ & $106.3(\mathrm{CH})$ & $6.55, \mathrm{dd}(8.6,2.4)$ & $107.3(\mathrm{CH})$ \\
\hline $6^{\prime}$ & $7.26, \mathrm{~d}(8.1)$ & $125.3(\mathrm{CH})$ & $7.07, \mathrm{~d}(8.6)$ & $127.9(\mathrm{CH})$ \\
\hline $1^{\prime \prime}$ & $4.84, \mathrm{~d}(7.7)$ & $100.5(\mathrm{CH})$ & $4.84, \mathrm{~d}(7.2)$ & $101.3(\mathrm{CH})$ \\
\hline
\end{tabular}


Table 3. Cont.

\begin{tabular}{|c|c|c|c|c|}
\hline \multirow{2}{*}{ No. } & \multicolumn{2}{|c|}{14} & \multicolumn{2}{|c|}{15} \\
\hline & $\delta_{\mathrm{H}}(J$ in $\mathrm{Hz})$ & $\delta_{C}$ (mult.) $^{a}$ & $\delta_{\mathrm{H}}(J$ in $\mathrm{Hz})$ & $\delta_{\mathrm{C}}$ (mult.) $^{\mathrm{a}}$ \\
\hline $2 "$ & $3.22, \mathrm{~m}$ & $73.3(\mathrm{CH})$ & $3.26, \mathrm{~m}$ & $73.6(\mathrm{CH})$ \\
\hline $3 "$ & $3.25, \mathrm{~m}$ & $76.7(\mathrm{CH})$ & $3.27, \mathrm{~m}$ & $77.0(\mathrm{CH})$ \\
\hline $4^{\prime \prime}$ & $3.14, \mathrm{~m}$ & $69.8(\mathrm{CH})$ & $3.15, \mathrm{~m}$ & $70.2(\mathrm{CH})$ \\
\hline $5^{\prime \prime}$ & $3.34, \mathrm{~m}$ & $77.2(\mathrm{CH})$ & $3.35, \mathrm{~m}$ & $77.5(\mathrm{CH})$ \\
\hline \multirow[t]{2}{*}{$6^{\prime \prime}$} & $3.67, \mathrm{~m}$ & $60.8\left(\mathrm{CH}_{2}\right)$ & $3.73, \mathrm{~m}$ & $61.1\left(\mathrm{CH}_{2}\right)$ \\
\hline & $3.44, \mathrm{~m}$ & & $3.46, \mathrm{~m}$ & \\
\hline $4^{\prime}-\mathrm{OCH}_{3}$ & $3.70, \mathrm{~s}$ & $55.4\left(\mathrm{CH}_{3}\right)$ & $3.72, \mathrm{~s}$ & $55.3\left(\mathrm{CH}_{3}\right)$ \\
\hline
\end{tabular}

Spasuberoside B ((3R)-vestitol-2'-O- $\beta$-D-glucopyranoside, 15): white powder $\left(\mathrm{MeCN}-\mathrm{H}_{2} \mathrm{O}\right)$; $[\alpha]^{25} \mathrm{D}^{-150.0}$ (c 0.2, MeOH); UV (MeOH) $\lambda_{\max } \mathrm{nm}(\log \varepsilon): 203$ (4.63), 224 (4.00), 283 (3.48); IR (KBr) $\gamma_{\max }: 3335,2916,2255,2127,1707,1615,1509,1459,1162,825 \mathrm{~cm}^{-1}$; for ${ }^{1} \mathrm{H}$ NMR and ${ }^{13} \mathrm{C}$ NMR data, see Table 3; HR-ESI-MS $m / z 433.1488[\mathrm{M}-\mathrm{H}]^{-}$(calculated for $\mathrm{C}_{22} \mathrm{H}_{25} \mathrm{O}_{9}, 433.1499$ ).

\subsection{ECD Calculation}

A Monte Carlo simulation was used to analyze the configurations of compounds using the MMFF94 molecular mechanics force field. The TDDFT method at the B3LYP/6-31G(d) level was used to optimize the conformation, the stability of which was confirmed by calculating the frequencies at the same level. After that, the TDDFT method at the B3LYP/6+31G(d) level with the CPCM model in $\mathrm{MeOH}$ was applied to calculate the ECD stable conformers. Gaussian 09 was used to calculate all relevant parameters, and SpecDis v 1.51 was used to simulate the ECD spectra with a half spectral bandwidth of $0.3 \mathrm{eV}$. Moreover, the ECD spectra were gained according to the Boltzmann-calculated contribution of different conformers.

\subsection{Structural Elucidation of Isolated Compounds 1-15}

Compounds (1-15) including five new ones $(2,5,6,14,15)$ afforded by the EtOAc and $n$-BuOH extractions were identified by spectroscopic analysis. The nine known compounds were further compared to the reported literature data and identified as 2,6-dimethoxy-1,4-benzoquinone (1) [16], 4,7,2'-trihydroxy-4'-methoxy-isoflavanol (3), liquiritigenin (8) [17], formononetin sodium (7) [18], genistein (9), formononetin (11), daidzein (12) [19], isoliquiritigenin (10) [20], and genistin (13) [21]. Their chemical structures are shown in Figure 1.

Compound 2 was obtained as a white powder. HR-ESI-MS demonstrated a negative ion at $\mathrm{m} / \mathrm{z}$ $331.0840[\mathrm{M}-\mathrm{H}]^{-}$(calculated for 331.0823), which corresponded to a molecular formula of $\mathrm{C}_{17} \mathrm{H}_{16} \mathrm{O}_{7}$. The IR spectrum of 2 showed maximum absorption bands due to a hydroxyl group $\left(3397 \mathrm{~cm}^{-1}\right)$ and aromatic ring $\left(1612,1458 \mathrm{~cm}^{-1}\right)$. The ${ }^{1} \mathrm{H}$ NMR and ${ }^{13} \mathrm{C}$ NMR data (Table 1) of 2 were similar to those of pumilanol [22], an isoflavanol, except for the coupling pattern of the A-ring in the ${ }^{1} \mathrm{H} N M R$ spectrum. Complete unambiguous assignments of the ${ }^{1} \mathrm{H}$ and ${ }^{13} \mathrm{C}$ NMR signals (Table 1 ) of 2 were made by combination of ${ }^{1} \mathrm{H}_{-}{ }^{1} \mathrm{H}$ COSY, HSQC, HMBC, and DEPT spectra. An HMBC experiment showed a methoxyl group at $\delta_{\mathrm{H}} 3.66(3 \mathrm{H}, \mathrm{s})$ correlating with carbon at $\delta_{\mathrm{C}} 135.8(\mathrm{C}-8)$, suggesting that this methoxyl group should be located at C-8. On this basis, the planar structure was identified as 7,2'-dihydroxy-8-methoxy-4', 5'-methylenedioxy-isoflavan-4-ol. Comparing to the reported data [23], a negative Cotton effect at $210 \mathrm{~nm}$ and a positive Cotton effect between $280 \mathrm{~nm}$ and $300 \mathrm{~nm}$ in the ECD spectrum revealed a $3 S, 4 R$ absolute configuration in 2 (Figure 2A). The key correlations in the ${ }^{1} \mathrm{H}-{ }^{1} \mathrm{H}$ COSY and HMBC spectra of $\mathbf{2}$ are shown in Figure 3. It was a novel compound, given the trivial name spasuberol A. 
<smiles>[R]c1c(O)ccc2c1OC[C@H](c1cc3c(cc1O)OCO3)[C@H](O)[C@H]2OC</smiles>

$4 \mathrm{R}=\mathrm{H}$<smiles>COc1ccc(-c2cc3cc(O)c(O)cc3oc2=O)c(OC)c1OC</smiles><smiles>COC1=CC(=O)C=C(OC)C1=O</smiles><smiles>[R20]c1ccc2c(c1)OC[C@H](c1ccc(OC)cc1O)[C@H]2O</smiles>

$14 \mathrm{R}=\mathrm{Glc}$<smiles>[R20]Oc1ccc(-c2coc3cc(O[R16])cc([R])c3c2=O)cc1</smiles>

$7 \mathrm{R}_{1}=\mathrm{H} \quad \mathrm{R}_{2}=\mathrm{Na} \quad \mathrm{R}_{3}=\mathrm{CH}_{3}$

$9 \mathrm{R}_{1}=\mathrm{OH} \quad \mathrm{R}_{2}=\mathrm{H} \quad \mathrm{R}_{3}=\mathrm{H}$

$11 \mathrm{R}_{1}=\mathrm{H} \quad \mathrm{R}_{2}=\mathrm{H} \quad \mathrm{R}_{3}=\mathrm{CH}_{3}$

$12 \mathrm{R}_{1}=\mathrm{H} \quad \mathrm{R}_{2}=\mathrm{H} \quad \mathrm{R}_{3}=\mathrm{H}$<smiles>CCCCCC(=O)CCC(=O)OCCc1ccc(O)c(OC)c1</smiles>

$13 \mathrm{R}_{1}=\mathrm{OH} \quad \mathrm{R}_{2}=\mathrm{Glc} \quad \mathrm{R}_{3}=\mathrm{H}$<smiles>O=C(/C=C/c1ccc(O)cc1)c1ccc(O)cc1O</smiles>

10<smiles>O=C1C[C@H](c2ccc(O)cc2)Oc2cc(O)ccc21</smiles><smiles>COc1ccc(C2COc3cc(O)ccc3C2)c(O[C]2O[C@H](CO)[C@@H](O)[C@H](O)[C@H]2O)c1</smiles>

15

Figure 1. The structures of compounds 1-15 isolated from the vine stems of Spatholobus suberectus.

A

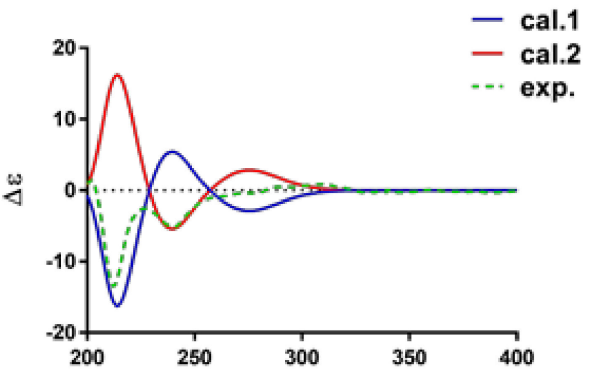

C

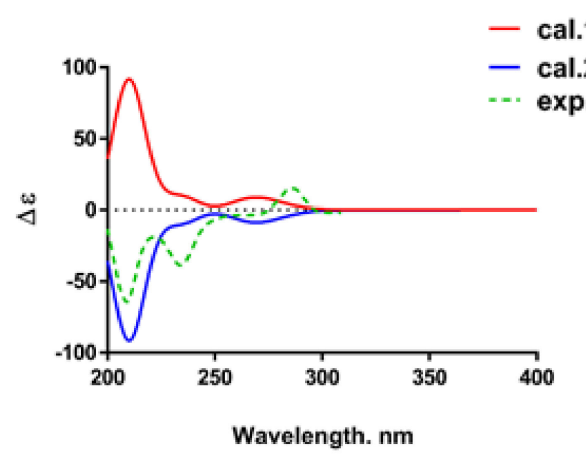

B
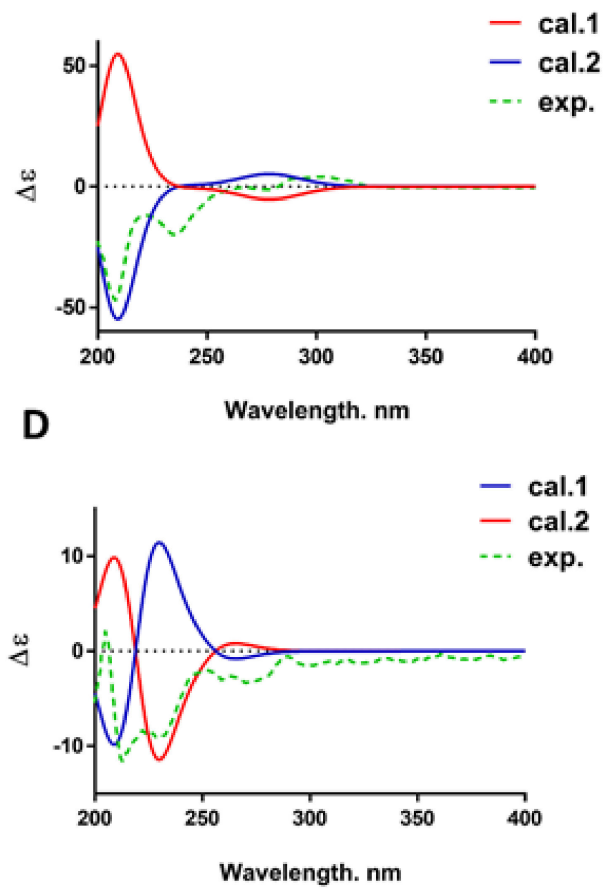

Figure 2. The ECD spectrum of compounds 2, 4, 14, and 15 (A-D). 

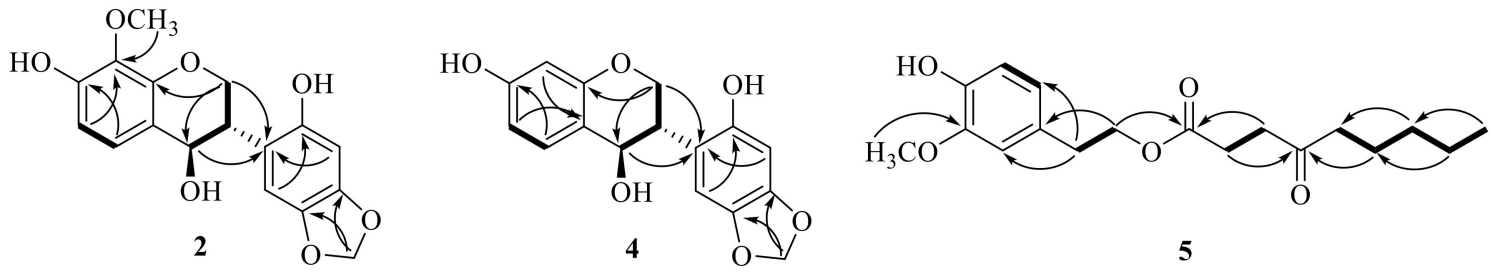

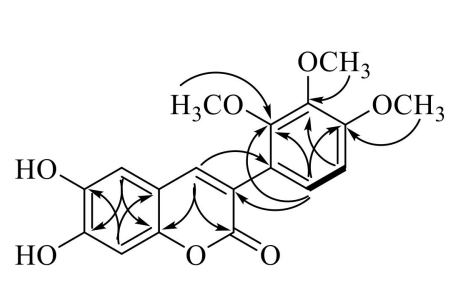

6

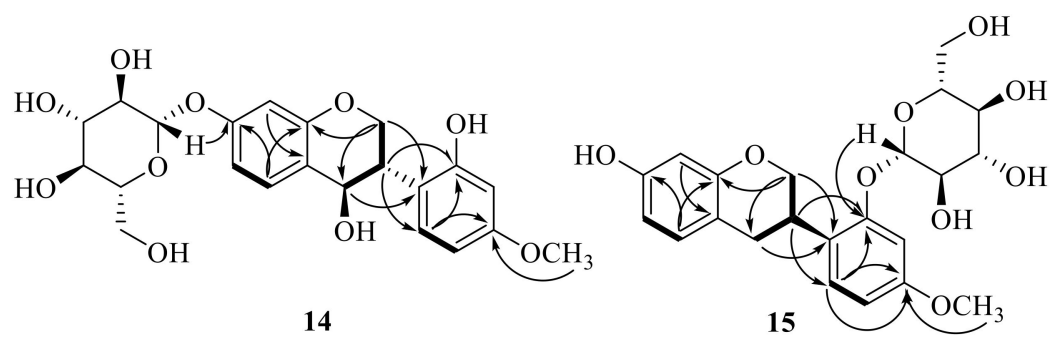

Figure 3. The ${ }^{1} \mathrm{H}-{ }^{1} \mathrm{H}$ COSY $(-)$ and key HMBC ( $\rightarrow$ from $\mathrm{H}$ to $\left.\mathrm{C}\right)$ correlations of compounds 2, 4-6, 14, and 15 .

Compound 4 was identified as a white powder with the molecular formula $\mathrm{C}_{16} \mathrm{H}_{14} \mathrm{O}_{6}$ according to the HR-ESI-MS ion of $m / z 285.0762\left[\mathrm{M}-\mathrm{H}_{2} \mathrm{O}+\mathrm{H}\right]^{+}$(calculated for 285.0763). The IR spectrum of 4 showed maximum absorption bands due to a hydroxyl group $\left(3250 \mathrm{~cm}^{-1}\right)$ and aromatic ring (1596, $1458 \mathrm{~cm}^{-1}$ ). All of the ${ }^{1} \mathrm{H}$ NMR and ${ }^{13} \mathrm{C}$ NMR data (Table 1) of 4 were similar to those of 2 except for the absence of a methoxyl group signal and an additional proton signal at $\delta 6.27$ $(1 \mathrm{H}, \mathrm{d}, J=2.4 \mathrm{~Hz}, \mathrm{H}-8)$ on the mother nucleus. Thus, the planar structure was identified as $7,2^{\prime}$-dihydroxy-4', $5^{\prime}$-methylenedioxy-isoflavan-4-ol. Although it was reported in a previous study [24], this is the first study to interpret its detailed structural information. Its configuration was $3 S, 4 R$ according to the CD and ECD spectra (Figure 2B). Based on the abovementioned structural data, the structure of 4 was identified as $(3 S, 4 R)-7,2^{\prime}$-dihydroxy- $4^{\prime}, 5^{\prime}$-methylenedioxyisoflavan-4-ol and given the trivial name spasuberol $\mathrm{B}$.

Compound 5 was a yellow-brown transparent oil. The molecular formula was $\mathrm{C}_{18} \mathrm{H}_{26} \mathrm{O}_{5}$ inferred from the HR-ESI-MS ion of $m / z 321.1699[\mathrm{M}-\mathrm{H}]^{-}$(calculated for 321.1702). The low-field region of its ${ }^{1} \mathrm{H}$ NMR (Table 2) indicated a benzene ring as part of this structure, of which the hydrogens on $\mathrm{C}-1$, $\mathrm{C}-3$, and C-4 were replaced by other substituent groups when conducting a further analysis combined with the ${ }^{13} \mathrm{C}$ NMR experiment (Table 2). A hydroxyl group proton at $\delta_{\mathrm{H}} 9.00(1 \mathrm{H}, \mathrm{s})$, a methoxyl group at $\delta_{\mathrm{H}} 3.74(3 \mathrm{H}, \mathrm{s})$, two linked methylenes at $\delta_{\mathrm{H}} 2.74(\mathrm{~J}=7.0 \mathrm{~Hz})$ and $\delta_{\mathrm{H}} 4.13(\mathrm{~J}=7.0 \mathrm{~Hz})$, and amyl group signals at $\delta_{\mathrm{H}} 0.85,1.25,1.45$, and 2.39 in the high nuclear magnetic field were found in the ${ }^{1} \mathrm{H}$ NMR spectrum. The ${ }^{13} \mathrm{C}$ NMR spectrum revealed two carbonyl groups at $\delta 172.4$ and 209.1, and two carbons signals at $\delta_{C} 147.6(\mathrm{C}-2)$ and $\delta_{C} 145.3$ (C-3) of the benzene ring, revealing the connections with hydroxyl and methoxyl groups, respectively. The HMBC correlations (Figure 3) indicated that the methoxyl group was attached to $C-3$, in line with the data from $\delta_{\mathrm{H}} 3.74$ to $\delta_{\mathrm{C}} 145.3$ (C-3). The relevance of $\mathrm{H}-7$ to $\mathrm{C}-1, \mathrm{C}-2$, and $\mathrm{C}-6$ indicated that $\mathrm{C}-7$ was linked to the $\mathrm{C}-1$ position. Furthermore, the chemical shift value of $C-8$ at $\delta_{C} 65.0$ was significantly higher than that of $C-7$, and the HMBC correlation of $\mathrm{H}-8$ and $\mathrm{C}-\mathrm{1}^{\prime}$ identified an oxygen atom between $\mathrm{C}-8$ and $\mathrm{C}-1^{\prime}$. C- $4^{\prime}$ was deemed a carbonyl carbon between $C-3^{\prime}$ and $C-5^{\prime}$ because of the lack of hydrogen on $C-4^{\prime}$. It was a novel compound, given the name homovanillyl-4-oxo-nonanoate.

The exterior trait of novel compound 6 was a yellow amorphous powder. Its molecular formula, $\mathrm{C}_{18} \mathrm{H}_{16} \mathrm{O}_{7}$, was established by the HR-ESI-MS ion of $m / z 345.0972\left[\mathrm{M}+\mathrm{H}^{+}\right.$(calculated for 345.0974). In the IR spectrum of 6 , the absorption band at $3301 \mathrm{~cm}^{-1}$ was caused by the hydroxyl group, whereas $1687 \mathrm{~cm}^{-1}$ represented the existence of $\alpha, \beta$-unsaturated six-membered lactone; these corollaries were further supported by the presence of a carbon signal at $\delta_{C} 160.5$ in the ${ }^{13} \mathrm{C}$ NMR spectrum. Its NMR spectroscopic data had a slight difference in the position of the substituents compared with that of 6,7-dihydroxy-3-( $3^{\prime}, 4^{\prime}, 5^{\prime}$-trimethoxyphenyl)chromenone [25], a coumarinoid compound. In the 
substituted group of C-3, the ${ }^{1} \mathrm{H}$ NMR data showed a pair of ortho-aromatic protons at $\delta_{\mathrm{H}} 6.64(1 \mathrm{H}, \mathrm{d}, J$ $=8.6 \mathrm{~Hz})$ and $\delta_{\mathrm{H}} 6.86(1 \mathrm{H}, \mathrm{d}, J=8.6 \mathrm{~Hz})$. In the HMBC experiment, the proton signal of $\delta_{\mathrm{H}} 6.86$ and $\delta_{\mathrm{H}} 6.64$ showed long-range correlation with the carbon signals of $\delta_{\mathrm{C}} 121.4(\mathrm{C}-3)$ and $\delta_{\mathrm{C}} 120.6\left(\mathrm{C}-1^{\prime}\right)$, respectively. Therefore, the signal $\delta_{\mathrm{H}} 6.86$ was assigned to the $\mathrm{H}-6^{\prime}$ and the signal $\delta_{\mathrm{H}} 6.64$ was assigned to the H-5'. Based on extensive analysis of the HMBC spectrum, significant long-range correlations were observed between $\delta_{\mathrm{H}} 6.86$ and $\delta_{\mathrm{C}} 151.8$, as well as between $\delta_{\mathrm{H}} 6.64$ and $\delta_{\mathrm{C}} 151.8,140.8$, and 120.6. Thereby, the signals of $\delta_{C} 151.8$ and $\delta_{C} 140.8$ belonged to C-4' and C-3'. Based on comprehensive analysis of the HSQC and HMBC spectral data, methoxyl groups at $\delta_{\mathrm{H}} 3.82(3 \mathrm{H}, \mathrm{s})$ and $\delta_{\mathrm{H}} 3.77(3 \mathrm{H}$, s) were linked to C-4' and C-3', respectively. Thus, the structure of 6 was determined as $3-\left(2^{\prime}, 3^{\prime}, 4^{\prime}\right.$ -trimethoxyphenyl)-6,7-dihydroxycoumarin, named spasuberol C.

Compound 14 was obtained as a white powder with the molecular formula $\mathrm{C}_{22} \mathrm{H}_{26} \mathrm{O}_{10}$, speculated from the HR-ESI-MS ion of $m / z 433.1499$ [M $\left.-\mathrm{H}_{2} \mathrm{O}+\mathrm{H}\right]^{+}$(calculated for 433.1499). The NMR spectra (Table 3) exhibited extra glucopyranosyl group signals in $\mathbf{1 4}$ when compared to the signals of 4,7,2' -trihydroxy-4'-methoxy-isoflavanol [17]. Its ${ }^{1} \mathrm{H}-{ }^{1} \mathrm{H}$ COSY correlations from $\mathrm{H}-6$ at $\delta_{\mathrm{H}} 3.74$ to $\mathrm{H}-5$ at $\delta_{\mathrm{H}} 7.39$ and $\mathrm{H}-8$ at $\delta_{\mathrm{H}} 6.56$ indicated that the glucopyranosyl group was maybe located at C-7 ( $\delta \mathrm{c}$ 158.6). Based on the HMBC correlation and HR-ESI-MS data, the relevance of H-1" at $\delta_{\mathrm{H}} 4.84$ and C-7 further confirmed that C-1" of the glucopyranosyl group was linked to C-7 via an oxygen bond. The negative and positive Cotton effects at $210 \mathrm{~nm}$ and around $290 \mathrm{~nm}$, respectively, in the ECD spectrum implied a $3 S, 4 R$ absolute configuration of 14 (Figure 2C). Finally, the structure of 14 was determined as $(3 S, 4 R)-4,2^{\prime}$-dihydroxy-4' -methoxyisoflavanol-7-glucopyranoside, named spasuberoside A.

Compound 15 was a white powder with the molecular formula $\mathrm{C}_{22} \mathrm{H}_{26} \mathrm{O}_{9}$ according to the HR-ESI-MS ion of $m / z 433.1488$ [M - H] $]^{-}$(calculated for 433.1499). The NMR spectral data of 15 were similar to those of (3R)-vestitol-7-O-glucoside [26] except for the connective position signals of a glucopyranosyl group. A hydroxyl group at $\delta_{\mathrm{H}} 9.13$ and a methoxyl group at $\delta_{\mathrm{H}} 3.72$ were found in the ${ }^{1} \mathrm{H}$ NMR spectrum. Correlations from H-6 at $\delta_{\mathrm{H}} 6.29$ to $\mathrm{H}-5$ at $\delta_{\mathrm{H}} 6.87$, and from H-6 ${ }^{\prime}$ at $\delta_{\mathrm{H}} 7.07$ to $\mathrm{H}-5^{\prime}$ at $\delta_{\mathrm{H}} 6.55$ based on ${ }^{1} \mathrm{H}-{ }^{1} \mathrm{H}$ COSY indicated two substituents on $\mathrm{C}-7$ and $\mathrm{C}-4^{\prime}$, and a deeper estimation from HSQC and HMBC correlations showed that the hydroxyl and methoxyl groups were linked together with C-7 and C-4', respectively. Furthermore, C-1" of the glucopyranosyl group was linked to C-2' via an oxyglycoside bond on the basis of the HMBC spectrum showing $\mathrm{H}-1^{\prime \prime}\left(\delta_{\mathrm{H}} 4.84\right)$ correlated to C-2' $\left(\delta_{C} 156.3\right)$. The CD and ECD data between $260 \mathrm{~nm}$ and $280 \mathrm{~nm}$ showed a negative Cotton effect (Figure 2D), which implied a $3 R$ absolute configuration at C-3. Accordingly, the structure of 15 was deduced as (3R)-vestitol-2'-O- $\beta$-D-glucopyranoside, a new member of the isoflavan group, named spasuberoside $B$.

\subsection{Activity of Inhibiting NO Overproduction}

As a kind of pro-inflammatory mediator, $\mathrm{NO}$ plays a complex role and participates in many different kinds of inflammatory reactions [27,28], the level of which usually varies to different pathological degrees. The isolated novel compounds and 10 known ones in this research were chosen to evaluate the activity of inhibiting NO released by RAW264.7 cells after being stimulated by LPS.

All the assayed compounds showed varying inhibitory activities on NO production, and the half maximal inhibitory concentration $\left(\mathrm{IC}_{50}\right)$ values are listed in Table 4. Compounds 1, 6-11 had potent inhibition, whilst the other eight ones had moderate inhibition activities compared with the inducible NO synthase inhibitor, L-N $N^{6}$-(1-iminoethyl)-lysine (L-NIL). Better yet, compounds 1 and 10 showed a more significant inhibitory effect on NO overproduction than L-NIL $(p<0.01)$, The median cytotoxic concentration $\left(\mathrm{CC}_{50}\right)$ and selectivity index (SI) values of compound 10 were $133.44 \mu \mathrm{M}$ and 19.68, respectively, which implied a lower cytotoxicity and a higher selectivity than compound $1\left(C_{50}\right.$ and SI values were $26.23 \mu \mathrm{M}$ and 4.61, respectively). When compared with indomethacin (IND), another positive drug in the study of anti-inflammatory, antipyretic, and analgesic properties [29,30], 
compounds 1, 8-10 displayed extremely significant effects on NO inhibition $(p<0.001)$, and the activities of compounds 7, 11, and 12 were also significantly better than that of IND $(p<0.01)$.

Table 4. The inhibitory activity of 15 compounds on nitric oxide (NO) production $(n=3)$.

\begin{tabular}{|c|c|c|c|}
\hline Compounds & $\mathrm{CC}_{50}(\mu \mathrm{M})$ & $\mathrm{IC}_{50}(\mu \mathrm{M})$ & $\mathrm{SI}^{\mathrm{a}}$ \\
\hline 1 & $26.23 \pm 1.26$ & $5.69 \pm 0.28 * * \mathbf{\Delta \Delta \Delta}$ & 4.61 \\
\hline 2 & $>200^{b}$ & $46.26 \pm 5.83$ & $>4.32$ \\
\hline 3 & $>200$ & $35.41 \pm 2.92$ \ & $>5.65$ \\
\hline 4 & $300.455 \pm 11.98$ & $40.05 \pm 6.94^{\wedge}$ & 7.50 \\
\hline 5 & $>200$ & $45.87 \pm 4.76$ & $>4.36$ \\
\hline 6 & $702.91 \pm 56.35$ & $28.33 \pm 6.44^{\wedge}$ & 24.81 \\
\hline 7 & $335.09 \pm 3.02$ & $22.75 \pm 0.55^{\boldsymbol{\Lambda}}$ & 14.73 \\
\hline 8 & $314.68 \pm 8.19$ & $16.34 \pm 4.45^{\mathbf{\Delta \Lambda \Delta}}$ & 19.25 \\
\hline 9 & $3557.01 \pm 925.86$ & $16.87 \pm 3.39 \boldsymbol{\Lambda \Lambda \Lambda}$ & 210.84 \\
\hline 10 & $133.44 \pm 2.11$ & $6.78 \pm 0.59 * * \mathbf{\Delta \Delta \Delta}$ & 19.68 \\
\hline 11 & $103.14 \pm 9.56$ & $21.11 \pm 4.80^{\boldsymbol{\Lambda}}$ & 4.88 \\
\hline 12 & $413.21 \pm 3.075$ & $35.49 \pm 2.69^{\Delta \Delta}$ & 11.64 \\
\hline 13 & $>200$ & $36.43 \pm 2.47^{\wedge}$ & 5.49 \\
\hline 14 & $718.30 \pm 110.98$ & $122.56 \pm 9.92$ & 5.86 \\
\hline 15 & 396.85 & $>200$ & $<1.98$ \\
\hline L-NIL & $>200$ & $19.08 \pm 1.18$ & $>10.48$ \\
\hline IND & $633.45 \pm 75.12$ & $55.44 \pm 3.71$ & 11.43 \\
\hline
\end{tabular}

\footnotetext{
a SI (Selectivity index) was calculated based on median cytotoxic concentration $\left(\mathrm{CC}_{50}\right)$ half maximal inhibitory concentration $\left(\mathrm{IC}_{50}\right) .{ }^{\mathrm{b}} \mathrm{CC}_{50}$ could not be obtained because of a cell survival rate $>98 \%$ at $200-6.25 \mu \mathrm{M} .{ }^{*} p<0.05,{ }^{* *}$ $p<0.01,{ }^{* * *} p<0.001$ vs. L- $N^{6}$-(1-iminoethyl)-lysine (L-NIL); $p<0.05,{ }^{\mathbf{\wedge}} p<0.01,{ }^{\mathbf{A \Lambda 4}} p<0.001$ vs. indomethacin (IND).
}

From Table 4, it is worth mentioning that the NO inhibitory activities of the selected aglycones were superior to the glycosides. Whether comparing compound 3 with $\mathbf{1 4}$ or 9 with $\mathbf{1 3}$, the inhibitory activities decreased significantly due to the 7-hydroxyl group replaced by a glucosyl group, in accordance with a previous study [31]. In addition, the flavonoids with a 4-carbanyl group showed a stronger anti-inflammatory activity on $\mathrm{NO}$ overproduction than compounds without the 4-carbanyl group. Comparing compounds 7, 11, and 12, the presence of sodium had little effect on activity; however, when the $4^{\prime}$-methoxyl group on ring B was substituted with a $4^{\prime}$-hydroxyl group, the inhibition activity also decreased relatively. Furthermore, seen from compounds 2 and $\mathbf{4}$, the activities were barely affected by the presence of the 8-methoxyl group.

\subsection{Analysis of Messenger RNA (mRNA) Expression Levels of Inflammatory Factors}

From a growth perspective, underlying mechanisms should be determined to explain how these compounds from SPC resist or reduce inflammation via inhibiting the excessive production of NO. The effects of compounds 1, 3, 4 and 6-13 on messenger ribonucleic acid (mRNA) expression levels of IL-6, pro-inflammatory cytokines interleukin $1 \beta$ (Il-1 $\beta$ ), TNF- $\alpha$, and proteases inducible nitric oxide synthase (iNOS), and COX-2 in RAW 264.7 cells were tested using qPCR (Figure 4; Figure 5). Some notable information from Figure 4; Figure 5 revealed that these compound concentrations dependently and markedly reduced the mRNA expression levels of the abovementioned cytokines and proteases, especially compound 1 at concentrations of $5 \mu \mathrm{M}$ and $10 \mu \mathrm{M}$ (Figure $4 \mathrm{~A}$ ). Compounds 3 and 4 , belonging to flavanols, could inhibit the mRNA expression of Il-1 $\beta$ at concentrations of $40 \mu \mathrm{M}$ and $50 \mu \mathrm{M}$, suggesting a moderate inhibitory activity compared with the other compounds (Figure 4B,C). Compared with the LPS group, the mRNA expressions of IL-1 $\beta$, TNF- $\alpha$ and iNOS were reduced significantly by compound 6 at concentrations of $20 \mu \mathrm{M}(p<0.01)$ and $30 \mu \mathrm{M}(p<0.001)$, which may be associated with the three methoxyl groups on this coumarin mother nucleus (Figure 4D). 

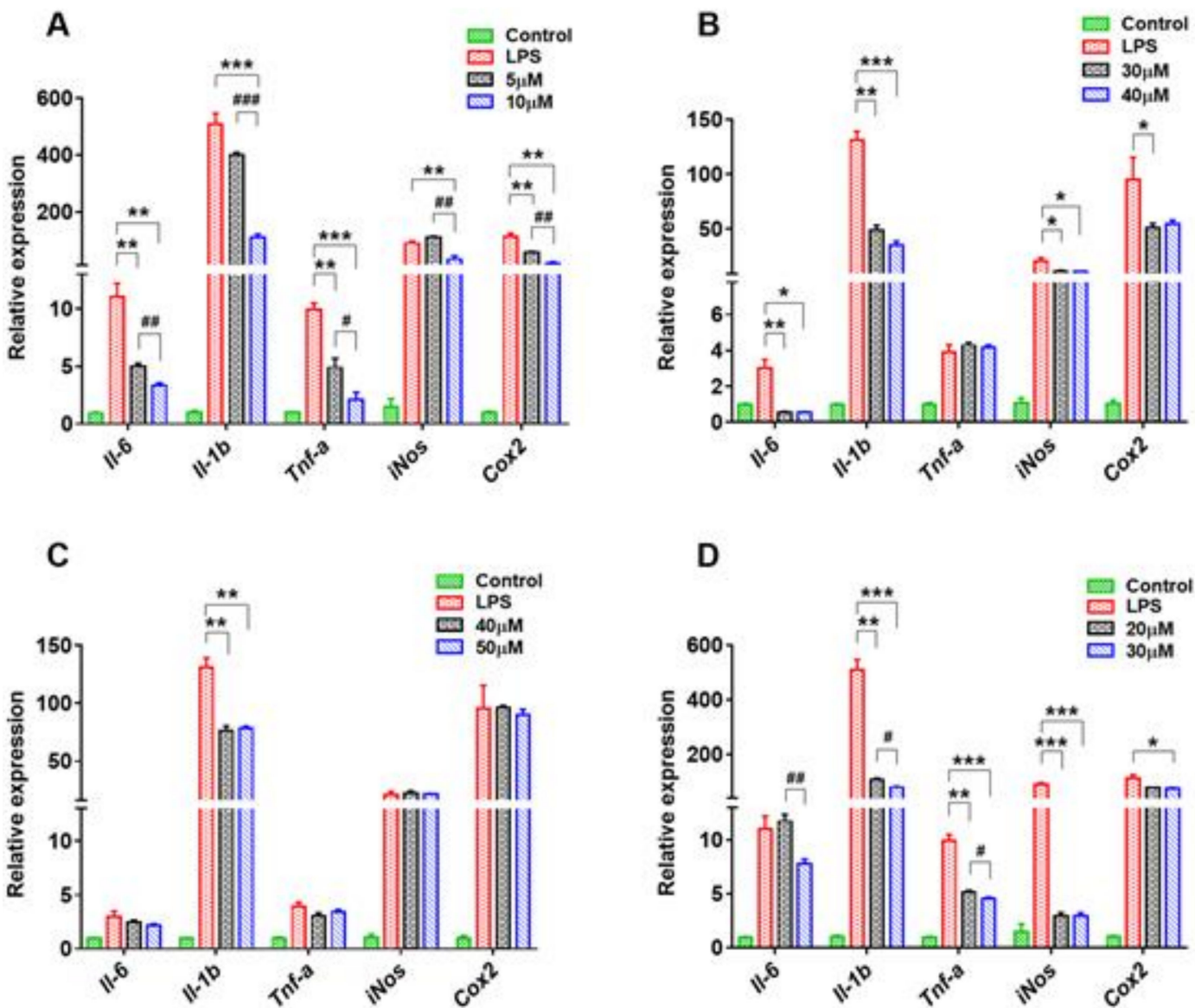

E
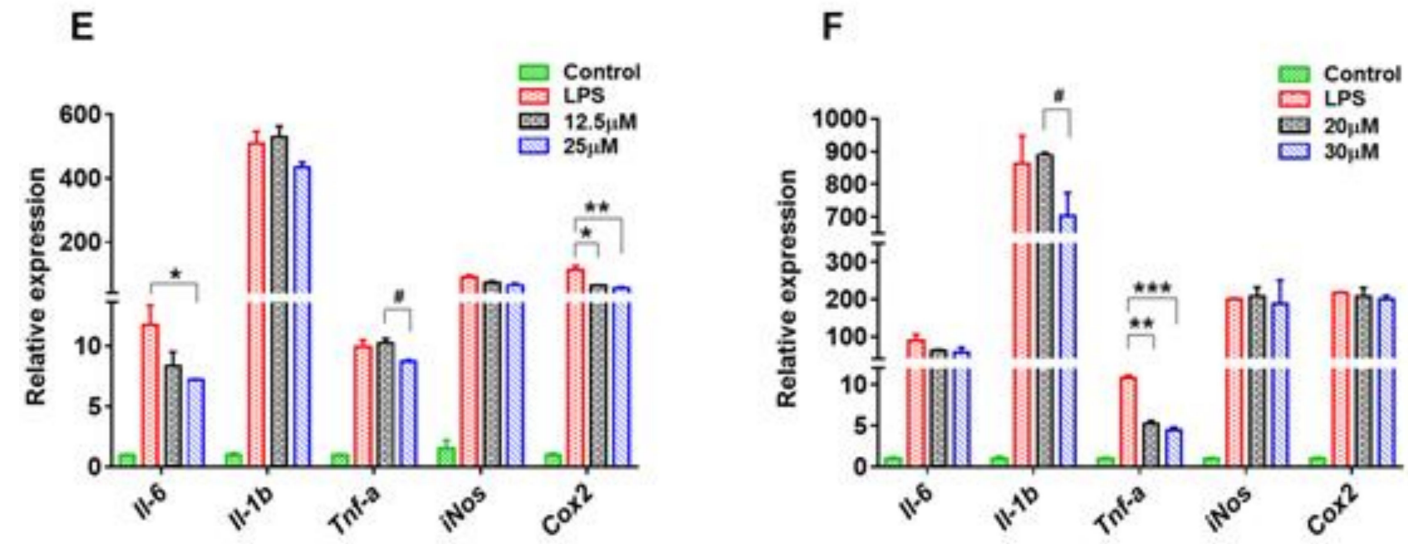

Figure 4. Effect of compounds 1, 3, 4, and 6-8 (A-F) on the messenger RNA (mRNA) levels of interleukin-6 (IL-6), IL-1 $\beta$, tumor necrosis factor $\alpha$ (TNF- $\alpha$ ), inducible nitric oxide synthase (iNOS), and cyclooxygenase 2 (COX-2) in RAW264.7 cells stimulated by lipopolysaccharide (LPS). Data are presented as means \pm standard error of the mean (SEM), $n=3{ }^{*} p<0.05,{ }^{* *} p<0.01,{ }^{* * *} p<0.001$, treatment vs. LPS model; ${ }^{\#} p<0.05,{ }^{\# \#} p<0.01,{ }^{\# \#} p<0.001$, high concentration vs. low concentration. 

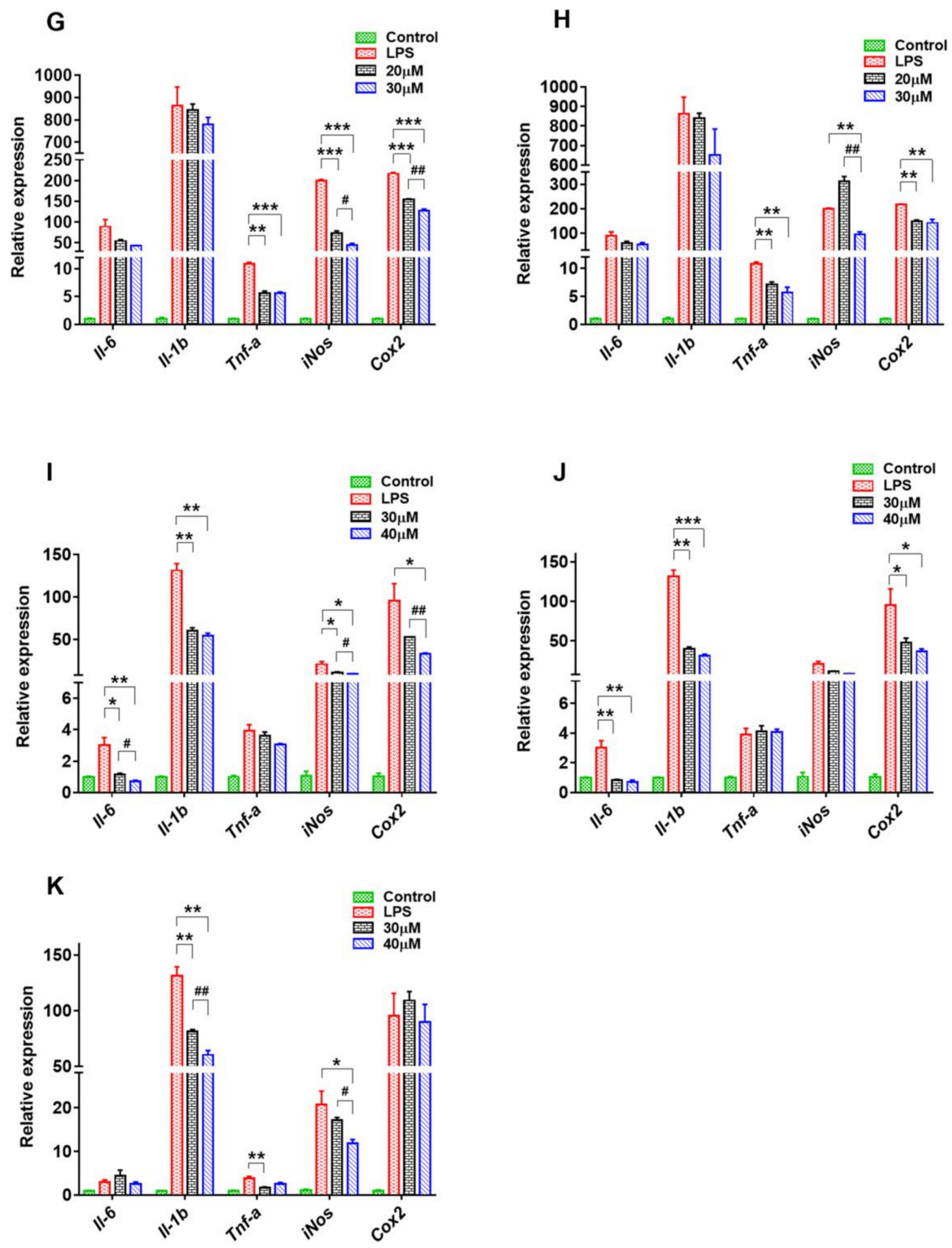

Figure 5. Effect of compounds 9-13 (G-K) on the mRNA levels of IL-6, IL-1 $\beta$, TNF- $\alpha$, iNOS, and COX-2 in RAW264.7 cells stimulated by LPS. Data are presented as means \pm SEM, $n=3$; ${ }^{*} p<0.05$, ** $p<0.01$, *** $p<0.001$, treatment vs. LPS model; ${ }^{*} p<0.05$, \#\# $p<0.01$, \#\# $p<0.001$, high concentration vs. low concentration.

Compounds 7, 11, and 12 influenced these mRNA expression levels to a certain degree (Figures $4 \mathrm{E}$ and $5 \mathrm{I}, \mathrm{J})$. In addition, compound $\mathbf{1 1}$ also notably downregulated the mRNA levels of iNOS and COX-2, in addition to the inhibition of mRNA levels of IL- 6 and IL-1 $\beta$ by compound 12, confirming that the $4^{\prime}$-methoxyl group on ring B may be a critical factor for these isoflavones to exhibit anti-inflammatory activity. The hydroxyl group at C-7 was also closely associated with the activity of 
compound 7. Once the proton was substituted by sodium, it seemed to negate the effect of compound 7 on these cytokines and proteases except for COX-2.

Compounds $\mathbf{8}$ and $\mathbf{1 0}$ are isomers with remarkable inhibitory function on NO overproduction, and both of them could significantly downregulate the mRNA expression of TNF- $\alpha$ (Figures $4 \mathrm{~F}$ and $5 \mathrm{H})$. Furthermore, both the NO overproduction and the mRNA levels of iNOS and COX-2 were more obviously inhibited when ring $C$ of compound 8 was opened. The mRNA levels of TNF- $\alpha$, iNOS, and COX-2 in RAW264.7 cells were strikingly downregulated when treated with compound 9 at concentrations of $20 \mu \mathrm{M}$ and $30 \mu \mathrm{M}$ (Figure 5G). Compared with compound 9, compound 13 with weaker inhibitory activity could not inhibit these three mRNA expressions (Figure 5K), but the mRNA level of IL-1 $\beta$ declined sharply, perhaps because of the existence of a glucose group at C-7.

The information motioned above indicated that either the satisfactory NO inhibitory activity or the regulation of mRNA expression of inflammatory factors was closely related to the chemical structures of these selected compounds. Compound $\mathbf{1}$ could be considered for structure modification to further reduce its cytotoxicity and increase its anti-inflammatory activity.

\section{Experimental Section}

\subsection{General Experimental Procedures}

The specific optical rotations were measured on Autopol III polarimeter (Rudolph Research Analytical, Flanders, NJ, USA). UV spectra were recorded using a Cary 300 UV-visible light (UV-Vis) spectrophotometer (Varian, Inc., Palo, Alto, CA, USA) with $\mathrm{MeOH}$ as the solvent, and IR spectra were determined by a Nexus 470 Fourier-transform IR (FT-IR) spectrometer (Thermo Nicolet, Inc., Madison, WI, USA) using the KBr squashed method. of the one- and two-dimensional (1D and 2D) NMR spectra were obtained from a Bruker AV 400 spectrometer (Bruker, Karlsruheb, Baden-Wuerttemberg, Germany), while tetramethylsilane (TMS) was used as the internal standard. High-resolution electron spray ionization mass spectrometry (HR-ESI-MS) was taken from a Waters Xevo G2 Q-TOF mass spectrometer (Waters, Milford, MA, USA).

Thin-layer chromatography (TLC) was carried out on silica gel $\mathrm{GF}_{254}$ plates (Merck, Darmstadt, Germany). Column chromatography (CC) was performed with silica gel (200-300 mesh, Qingdao Marine Chemical Factory, China). Sephadex LH-20 was purchased from Mitsubisi Petrochemical Co. (Mitsubisi Petrochemical Co., Tokyo, Japan). Compounds were isolated and further purified by a reversed-phase semi-preparative HPLC (RPSP-HPLC) system equipped with an LC3000 UV detector, a LabTech P600 pump, and a 7725i Rheodyne injector (Rheodyne, Cotati, CA, USA) with a loop of $5 \mathrm{~mL}$, and a preparative Phenomenex Prodigy $\mathrm{C}_{18}$ column $(250 \times 21.2 \mathrm{~mm}$ inner diameter (i.d.), $10 \mu \mathrm{m}$; Phenomenex, Torrance, CA, USA) protected by a $\mathrm{C}_{18}$ guard column $(8 \times 4 \mathrm{~mm}$ i.d., $5 \mu \mathrm{m}$; Dikma, Beijing, China). A CXTH 3000 Chromsoftware workstation was used to maintain and test the operating state.

$\mathrm{MeCN}$ and $\mathrm{MeOH}$ (HPLC grade) were purchased from Fisher Scientific (Fair lawn, NJ, USA). $\mathrm{MeOH}, \mathrm{EtOAc}, \mathrm{CHCl}_{3}, n$-BuOH, isopropanol, and absolute alcohol (analytical grade) were purchased from Beijing Chemical Works (Beijing, China). Dulbecco's modified Eagle's medium (DMEM), fetal bovine serum (FBS), penicillin-streptomycin solution, and phosphate-buffered saline (PBS) were purchased from Gibco ${ }^{\mathrm{TM}}$ (Life Technologies Inc., Grand Island, NY, USA). LPS, Griess reagent, 3-(4,5-dimethyl-2-thiazolyl)-2,5-diphenyl-2H-tetrazoliumbromide (MTT), L-NIL, and IND were obtained from Sigma Aldrich Co. (St. Louis, MO, USA). The RAW264.7 cells were supplied by the Cell Resource Center, IBMS, CAMS/PUMC (Beijing, China).

\subsection{Plant Material}

The dried vine stems of Spatholobus suberectus were harvested from Pu'er city, Yunnan Province, China $\left(23^{\circ} 19^{\prime}\right.$ north (N), $100^{\circ} 30^{\prime}$ east (E)) and kindly supplied by Zhuzhou Qianjin Pharmaceutical Co., Ltd. The species was identified by Prof. Xiu-Wei Yang at the School of Pharmaceutical Sciences, Peking 
University Health Science Center, Peking University. A voucher specimen (No. Y008-1608010) is stored at the State Key Laboratory of Natural and Biomimetic Drugs (Peking University, Beijing, China).

\subsection{Biological Study}

\subsubsection{Cytotoxicity Assay}

The toxicities of different concentrations of compounds to cells were evaluated using the MTT assay [32,33]. Firstly, the RAW 264.7 cells were maintained in DMEM with $10 \%$ FBS at $37^{\circ} \mathrm{C}$ in a humid atmosphere containing $5 \% \mathrm{CO}_{2}$. Then, the cells were seeded in 96 -well plates $\left(3 \times 10^{4}\right.$ cells/well) after being passaged three times at a 1:3 split ratio. A sequence of concentrations of the tested compounds $(3.12 \mu \mathrm{M}-200 \mu \mathrm{M})$ with or without LPS $(1 \mu \mathrm{g} / \mathrm{mL})$ was added to stimulate cells for $24 \mathrm{~h}$. After being cultured for $24 \mathrm{~h}$, the supernatant $(100 \mu \mathrm{L})$ was transferred out and MTT $(5 \mathrm{mg} / \mathrm{mL}, 20 \mu \mathrm{L}$ for each well) was added, and the mixed solvent of $0.012 \mathrm{M} \mathrm{HCl}, 5 \% \mathrm{i}-\mathrm{PrOH}$, and $10 \%$ sodium dodecyl sulfate $(100 \mu \mathrm{L})$ was added $4 \mathrm{~h}$ later. The absorbance value was measured at $492 \mathrm{~nm}$ by a Thermo Multiskan MK3 microplate reader (Thermo-Labsystem, Franklin, MA, USA).

\subsubsection{NO Inhibition Assay}

The Griess method is generally used for determining NO concentration in anti-inflammatory experiments [34,35]. The supernatant removed from the 96-well plates mentioned in Section 3.3.1 was interacted with Griess reagent $(100 \mu \mathrm{L})$, and the absorbance was measured at $540 \mathrm{~nm}$ after $15 \mathrm{~min}$. Two drugs, L-NIL and IND, were used as positive controls for comparative analysis in the test.

\subsection{3. qPCR Assay}

The RAW264.7 cells were seeded in 12-well plates at $3 \times 10^{4}$ cells/well; after being stimulated by LPS $(1.0 \mu \mathrm{g} / \mathrm{mL})$ and treated with two different concentrations of compounds for $24 \mathrm{~h}$, the total RNA was extracted from the cells with Trizol reagent (Invitrogen, Thermo Fisher Scientific Inc., Waltham, MA, USA). After measuring the concentration, $1 \mu \mathrm{g}$ of total RNA was used to obtain complementary DNA (cDNA) with a qRT super mix (Bimake Co., Ltd., Houston, SD, USA). The amplification of cDNA was carried out on a Quantitative RT-PCR system (Agilent Technologies, Stratagene, Inc., Santa Clara, CA, USA) using SYBR green qPCR master mix (Bimake Co., Ltd., Houston, SD, USA). The thermal cycling conditions were as follows: $95^{\circ} \mathrm{C}$ for $10 \mathrm{~min}, 40$ cycles of $95^{\circ} \mathrm{C}$ for $30 \mathrm{~s}, 55^{\circ} \mathrm{C}$ for $1 \mathrm{~min}$, and $72{ }^{\circ} \mathrm{C}$ for $1 \mathrm{~min}$, followed by $95^{\circ} \mathrm{C}$ for $1 \mathrm{~min}, 55^{\circ} \mathrm{C}$ for $30 \mathrm{~s}$, and $95^{\circ} \mathrm{C}$ for $30 \mathrm{~s}$. The sequences of the primers used in our experiment are listed in Table 5.

Table 5. The sequences of the primers for qPCR.

\begin{tabular}{ccc}
\hline Gene & Forward $\left(\mathbf{5}^{\prime} \mathbf{-} \mathbf{3}^{\prime} \mathbf{)}\right.$ & Reverse $\left(\mathbf{5}^{\prime} \mathbf{-} \mathbf{3}^{\prime} \mathbf{)}\right.$ \\
\hline$\beta$-Actin & GGCTGTATTCCCCTCCATCG & CCAGTTGGTAACAATGCCATGT \\
IL-6 & TAGTCCTTCCTACCCCAATTTCC & TTGGTCCTTAGCCACTCCTTC \\
IL-1 $\beta$ & TCAGGCAGGCAGTATCACTC & AGCTCATATGGGTCCGACAG \\
TNF- $\alpha$ & ATGGCCTCCCTCTCATCAGT & TGGTTTGCTACGACGTGGG \\
iNOS & TCCATGACTCCCAGCACA & CCATCTCCTGCATTTCTTCC \\
COX- 2 & GGCGCAGTTTATGTTGTCTGT & CAAGACAGATCATAAGCGAGGA \\
\hline
\end{tabular}

\subsubsection{Statistical Analysis}

The $\mathrm{IC}_{50}$ values for NO inhibitory effects were calculated using SPSS v.20.0 (SPSS Inc., Chicago, IL, USA) and results were given as means \pm SD. The mRNA expression levels were compared using variance analysis with GraphPad Prism 7.0 (GraphPad Software Inc., San Diego, CA, USA), and results were expressed as means \pm SEM. All tests were carried out in triplicate. 


\section{Conclusions}

In conclusion, five new and 10 known compounds were isolated and identified from the vine stem of S. suberectus in the current study. Despite there being no novel maternal nucleus skeleton found in these new compounds, the research still further enriched the compound library of SPC, and made a clear comparison with some known compounds sharing the same mother nucleus in terms of toxicity and activity. According to the results of inhibition of the overproduction of NO in Raw264.7 cells induced by LPS, compound 1, 2,6-dimethoxy-1,4-benzoquinone, showed the best activity but the highest cytotoxicity compared to the other assayed compounds because of its structural particularity. Therefore, the aims of toxicity reduction and efficiency enhancement could be achieved by structural modification. In general, flavonoid aglycones have stronger anti-inflammatory activity than their corresponding glycosides [36], where the glycosylation of some substituent groups may bring an important effect on the activities. The double bonds, especially at C-2/C-3 of ring C, in the flavonoid structure play a critical role in the anti-inflammatory activity $[37,38]$, but not in isoflavone according to the results of research. Compounds 7, 9, 11, 12, and $\mathbf{1 3}$ showed similar NO inhibitory activities but different downregulated mRNA expressions of inflammatory factors; this functional difference may be related to the number and position of hydroxyl groups. Generally speaking, active compounds are the basic elements of TCM, as well as the main material base for disease treatment; thus, these compounds from SPC could be used as prototypes or lead compounds in the research and development of innovative drugs for treating inflammatory diseases, and further studies should be developed to evaluate the intracorporal process to reach the goal of elucidating the true material basis of their pharmacodynamics.

Author Contributions: X.-W.Y. and P.Z. conceptualized and designed the experiments; X.-Y.L., Y.-B.Z., Y.-F.Y., W.X., W.Z., K.-F.P., Y.G., N.-F.L., and P.Z. performed the experiments and analyzed the data; X.-Y.L. and Y.-B.Z. wrote the paper; X.-W.Y. polished the paper; X.-W.Y. and P.Z. acquired funding for the research. All authors read and approved the final manuscript.

Funding: This research was supported by the National Chinese Medicine Standardization Project (2YB2H-C-HUN-21).

Conflicts of Interest: The authors declare no conflicts of interest.

\section{References}

1. Chinese Pharmacopoeia Commission. Pharmacopoeia of the People's Republic of China; China Medical Science and Technology Press: Beijing, China, 2015; Volume I, p. 194.

2. Chen, S.R.; Wang, A.Q.; Lin, L.G.; Qiu, H.C.; Wang, Y.T.; Wang, Y. In vitro study on anti-hepatitis C virus activity of Spatholobus suberectus Dunn. Molecules 2016, 21, 1367. [CrossRef] [PubMed]

3. Lee, B.J.; Jo, I.Y.; Bu, Y.; Park, J.W.; Maeng, S.; Kang, H.; Jang, W.; Hwang, D.S.; Lee, W.; Min, K.; et al. Antiplatelet effects of Spatholobus suberectus via inhibition of the glycoprotein $\mathrm{Ilb} / \mathrm{III}$ receptor. J. Ethnopharmacol. 2011, 134, 460-467. [CrossRef] [PubMed]

4. Lu, S.L.; Wu, B.Y.; Chong, X.Z.; Yan, P.; Zhan, R.T.; Zhang, S.R. Effect of ethanol extracts from Caulis Spatholobi on blood lipid and their antioxidation in hyperlipemia rats. J. Guangzhou Univ. Tradit. Chin. Med. 2017, 34, 387-390.

5. Ravipati, A.S.; Zhang, L.; Koyyalamudi, S.R.; Jeong, S.C.; Reddy, N.; Bartlett, J.; Smith, P.T.; Shanmugam, K.; Münch, G.; Wu, M.J.; et al. Antioxidant and anti-inflammatory activities of selected Chinese medicinal plants and their relation with antioxidant content. BMC Complement Altern. Med. 2012, 12, 173. [CrossRef] [PubMed]

6. Fu, Y.F.; Jiang, L.H.; Zhao, W.D.; Xi-Nan, M.; Huang, S.Q.; Yang, J.; Hu, T.J.; Chen, H.L. Immunomodulatory and antioxidant effects of total flavonoids of Spatholobus suberectus Dunn on PCV2 infected mice. Sci. Rep. 2017, 7, 8676. [CrossRef] [PubMed]

7. Chen, H.L.; Yang, J.; Fu, Y.F.; Meng, X.N.; Zhao, W.D.; Hu, T.J. Effect of total flavonoids of Spatholobus suberectus Dunn on PCV2 induced oxidative stress in RAW264.7 cells. BMC Complement Altern. Med. 2017, 17, 244. [CrossRef] 
8. Do, M.H.; Hur, J.; Choi, J.; Kim, Y.; Park, H.Y.; Ha, S.K. Spatholobus suberectus ameliorates diabetes-induced renal damage by suppressing advanced glycation end products in db/db mice. Int. J. Mol. Sci. 2018, 19, 2774. [CrossRef]

9. Li, H.; Ji, G.Y.; Wang, Y.Q.; Deng, Y.X.; Lin, F.Y.; Jiang, Z.Q. Effect of genistein on cholesterol metabolism and expressions of gene or protein involved in SREBP-2 pathway in HepG2 cells. South Chin. J. Prev. Med. 2014, 40, 114-118.

10. Kim, H.Y.; Kim, A.R.; Seo, H.S.; Baik, J.E.; Ahn, K.B.; Yun, C.H.; Han, S.H. Lipoproteins in Streptococcus gordonii are critical in the infection and inflammatory responses. Mol. Immunol. 2018, 101, 574-584. [CrossRef]

11. Tocmo, R.; Parkin, K. S-Alk(en)ylmercaptocysteine suppresses LPS-induced pro-inflammatory responses in murine macrophages through inhibition of NF-kappaB pathway and modulation of thiol redox status. Free Radic. Biol. Med. 2018, 129, 548-558. [CrossRef]

12. Kang, S.S.; Sim, J.R.; Yun, C.H.; Han, S.H. Lipoteichoic acids as a major virulence factor causing inflammatory responses via Toll-like receptor 2. Arch. Pharm. Res. 2016, 39, 1519-1529. [CrossRef] [PubMed]

13. Shen, C.Y.; Jiang, J.G.; Shi, M.M.; Yang, H.L.; Wei, H.; Zhu, W. Comparison of the effects and inhibitory pathways of the constituents from Gynostemma pentaphyllum against LPS-induced inflammatory response. J. Agric. Food Chem. 2018, 66, 11337-11346. [CrossRef] [PubMed]

14. Xu, J.; Wang, M.; Sun, X.; Ren, Q.; Cao, X.; Li, S.; Su, G.; Tuerhong, M.; Lee, D.; Ohizumi, Y.; et al. Bioactive terpenoids from Salvia plebeia: Structures, NO inhibitory activities, and interactions with iNOS. J. Nat. Prod. 2016, 79, 2924-2932. [CrossRef] [PubMed]

15. Jang, J.; Jung, Y.; Chae, S.; Bae, T.; Kim, S.M.; Shim, Y.J.; Chung, S.I.; Yoon, Y. XAV939, a Wnt/beta-catenin pathway modulator, has inhibitory effects on LPS-induced inflammatory response. Immunopharmacol. Immunotoxicol. 2019, 41, 394-402. [CrossRef] [PubMed]

16. Guo, X.D.; An, L.K.; Xu, D.; Ma, L.; Gu, L.Q. The chemical constituents of Heliicteres angustifolia Linn. Acta Scinetiarum Nat. Univ. Sunyatseni 2003, 42, 52-55.

17. Tang, R.N.; Qu, X.B.; Guan, S.H.; Xu, P.P.; Shi, Y.Y.; Guo, D.A. Chemical constituents of Spatholobus suberectus. Chin. J. Nat. Med. 2012, 10, 32-35. [CrossRef]

18. Zheng, Y.; Liu, H.; Bai, Y.J.; Ma, Y.M.; Zhao, Y.Y. Five flavonoids from Spatholobus suberectus. Chin. J. Chin. Mater. Med. 2008, 33, 152-154.

19. Wu, S.; Xu, W.; Yang, X.W. Studies on biotransformation of chemical constituents of Tongmai formula by human intestinal flora. Chin. J. Chin. Mater. Med. 2013, 38, 3510-3519.

20. Wang, Q.H.; Wang, X.L.; Ao, W.L.J.; Dai, N.Y.T.; Na, R.C.K.T. Chemical constituents of roots of Astragalus membranaceus (Fisch.) Bge. var. mongholicus (Bge) Hsiao. Chin. Pharm. J. 2014, 49, 357-359.

21. Wang, K.H.; Zhang, Y.T.; Yang, X.W.; Xu, W.; Zhang, P.; Gong, Y.; Liu, N.F. Chemical constituents from Fukeqianjin formula. Chin. J. Chin. Mater. Med. 2018, 43, 2300-2312.

22. Ganapaty, S.; Pannakal, S.T.; Srilakshmi, G.V.K.; Lakshmi, P.; Waterman, P.G.; Brun, R. Pumilanol, an antiprotozoal isoflavanol from Tephrosia pumila. Phytochem. Lett. 2008, 1, 175-178. [CrossRef]

23. Won, D.; Shin, B.K.; Kang, S.; Hur, H.G.; Kim, M.; Han, J. Absolute configurations of isoflavan-4-ol stereoisomers. Bioorg. Med. Chem. Lett. 2008, 18, 1952-1957. [CrossRef] [PubMed]

24. Cho, H.; Chung, B.; Kim, C.K.; Oh, D.C.; Oh, K.B.; Shin, J. Spatholobus suberectus Dunn. constituents inhibit sortase A and Staphylococcus aureus cell clumping to fibrinogen. Arch. Pharmacal Res. 2017, 40, 518-523. [CrossRef] [PubMed]

25. Danis, O.; Demir, S.; Gunduz, C.; Alparslan, M.M.; Altun, S.; Yuce-Dursun, B. Synthesis of selected 3- and 4-arylcoumarin derivatives and evaluation as potent antioxidants. Res. Chem. Intermed. 2016, 42, 6061-6077. [CrossRef]

26. Hatano, T.; Takagi, M.; Ito, H.; Yoshida, T. Acylated flavonoid glycosides and accompanying phenolics from licorice. Phytochemistry 1998, 47, 287-293. [CrossRef]

27. Chen, H.C.; Lee, J.K.; Yip, T.; Sernia, C.; Lavidis, N.A.; Spiers, J.G. Sub-acute restraint stress progressively increases oxidative/nitrosative stress and inflammatory markers while transiently upregulating antioxidant gene expression in the rat hippocampus. Free Radic. Biol. Med. 2019, 130, 446-457. [CrossRef]

28. Cheong, S.H.; Yang, H.W.; Ko, E.Y.; Ahn, G.; Lee, W.; Kim, D.; Jeon, Y.J.; Kim, K.N. Anti-inflammatory effects of trans-1,3-diphenyl-2,3-epoxypropane-1-one in zebrafish embryos in vivo model. Fish Shellfish Immunol. 2016, 50, 16-20. [CrossRef] 
29. Abdallah, H.M.I.; Elshamy, A.I.; El Gendy, A.E.G.; Abd El-Gawad, A.M.; Omer, E.A.; De Leo, M.; Pistelli, L. Anti-inflammatory, antipyretic, and antinociceptive effects of a Cressa cretica aqueous extract. Planta Med. 2017, 83, 1313-1320. [CrossRef]

30. Nalamachu, S.; Wortmann, R. Role of indomethacin in acute pain and inflammation management: A review of the literature. Postgrad. Med. 2014, 126, 92-97. [CrossRef]

31. Rotelli, A.E.; Guardia, T.; Juarez, A.O.; de la Rocha, N.E.; Pelzer, L.E. Comparative study of flavonoids in experimental models of inflammation. Pharmacol. Res. 2003, 48, 601-606. [CrossRef]

32. Scherliess, R. The MTT assay as tool to evaluate and compare excipient toxicity in vitro on respiratory epithelial cells. Int. J. Pharm. 2011, 411, 98-105. [CrossRef] [PubMed]

33. Deng, G.G.; Wei, W.; Yang, X.W.; Zhang, Y.B.; Xu, W.; Gong, N.B.; Lu, Y.; Wang, F.F. New coumarins from the roots of Angelica dahurica var. formosana cv. Chuanbaizhi and their inhibition on NO production in LPS-activated RAW264.7 cells. Fitoterapia 2015, 101, 194-200. [PubMed]

34. Cianciulli, A.; Calvello, R.; Porro, C.; Trotta, T.; Salvatore, R.; Panaro, M.A. PI3k/Akt signalling pathway plays a crucial role in the anti-inflammatory effects of curcumin in LPS-activated microglia. Int. Immunopharmacol. 2016, 36, 282-290. [CrossRef] [PubMed]

35. Wu, X.W.; Wei, W.; Yang, X.W.; Zhang, Y.B.; Xu, W.; Yang, Y.F.; Zhong, G.Y.; Liu, H.N.; Yang, S.L. Anti-inflammatory phenolic acid esters from the roots and rhizomes of Notopterygium incisium and their permeability in the human Caco-2 monolayer cell model. Molecules 2017, 22, 935. [CrossRef] [PubMed]

36. Weng, Z.M.; Wang, P.; Ge, G.B.; Dai, Z.R.; Wu, D.C.; Zou, L.W.; Dou, T.Y.; Zhang, T.Y.; Yang, L.; Hou, J. Structure-activity relationships of flavonoids as natural inhibitors against $E$. coli beta-glucuronidase. Food Chem. Toxicol. 2017, 109, 975-983. [CrossRef]

37. Lago, J.H.; Toledo-Arruda, A.C.; Mernak, M.; Barrosa, K.H.; Martins, M.A.; Tiberio, I.F.; Prado, C.M. Structure-activity association of flavonoids in lung diseases. Molecules 2014, 19, 3570-3595. [CrossRef]

38. Wu, J.; Liu, K.; Shi, X.H. The anti-inflammatory activity of several flavonoids isolated from Murraya paniculata on murine macrophage cell line and gastric epithelial cell (GES-1). Pharm. Biol. 2016, 54, 868-881. [CrossRef]

Sample Availability: Samples of the compounds are not available from the authors.

(C) 2019 by the authors. Licensee MDPI, Basel, Switzerland. This article is an open access article distributed under the terms and conditions of the Creative Commons Attribution (CC BY) license (http://creativecommons.org/licenses/by/4.0/). 